\title{
A High Voltage Gain Multiport Zeta-Zeta Converter for Renewable Energy Systems
}

\author{
Ilambirai Raghavan Chandran, Sridhar Ramasamy, Chellammal Nallaperumal
}

SRM Institute of Science and Technology, Department of Electrical and Electronics Engineering, Kancheepuram District, Chennai, Tamilnadu, India.

\begin{abstract}
In this paper, a zeta-zeta coupled non-isolated multiport converter is proposed and implemented. This new dc-dc multiport converter facilitates the access of two renewable energy sources in the input side with a single output. Zeta converter topology facilitates high voltage gain with a reduced output voltage ripple. Multiport converters have become very prominent in the recent past due to the prevalent establishments of distributed energy resources. But in the research arena, there is no literature evidence for Zeta -Zeta converters used in multiport converters. This research work proposes a Zeta-Zeta multiport converter with reduced number of switches for renewable energy systems. The proposed converter is simulated in MATLAB/ Simulink environment and is also realized as a hardware prototype. The voltage gain and efficiency of the proposed circuit is compared with its counterpart multiport topologies. The simulation and hardware results show that the proposed topology is having a clear edge on its counter parts in voltage gain and efficiency.
\end{abstract}

\section{Več vhodni zeta-zeta pretvornik z visokim napetostnim ojačenjem za sisteme obnovljivih virov}

\begin{abstract}
Izvleček: Članek opisuje neizoliran več vhodni zeta-zeta pretvornik. Nov dc-dc pretvornik omogoča priklop dveh obnovljivih virov na vhodu in skupen izhod. Topologija zeta pretvornika omogoča visoko napetostno ojačenje in znižan izhoden ripple. Več vhodni pretvorniki so postali pomembni v zadnjih letih s pojavom distribuiranih virov energije. Kljub temu v literaturi ni opaziti navedb zetazeta pretvornikov. Predlagan več vhodni pretvornih z znižanim številom stikal je simuliran v MATLAB/Simulink okolju in realiziran kot prototip. Napetostno ojačenje in izkoristek sta primerljiva s konkurenčnimi topologijami.
\end{abstract}

Ključne besede: obnovljivi viri; dc-dc pretvornik; več vhodni pretvornik; zeta pretvornik; fotovoltaika; baterije.

*Corresponding Author's e-mail: sridharr@srmist.edu.in; sridharmanly@gmail.com

\section{Introduction}

In the present scenario, the increase in power demand with depleting conventional energy resources urges to have power generation through renewable energy sources. Renewable energies like solar, wind and fuel cells of different capacities are being deployed to meet the additional demand. Thus, high penetration of sustainable energy into the grid paves way for the development of integrated power converters which facilitates appropriate synchronization. These are capa- ble of interfacing and controlling the energy from the various input terminals. Multiport converters are capable of optimizing the power from various renewable sources with optimum switches. Owing to the striking merits such as low cost and small structure, many multiport configurations have been offered for numerous applications such as for satellites, hybrid electric vehicle etc,[1]. The multiport converter topologies are competent enough to interface and regulate many power sources as shown in Figure1. But due to this 
there is a chance of increase in number of switches in the circuit and the efficiency may reduce[2].Hence, the research on proposing new topologies with multi input structures thereby optimizing the number of switches has become very vital. H.Matsuo proposed a buckboost converter that accommodates two inputs with a magnetic coupling reactor [3]. A solid-state transformer (SST) based quad active converter bridge is implemented in [4], wherein SST provides isolation from the load. Here, the number of active devices involved in the circuit is more which is a major drawback. Hence, isolated multiple dc-dc converter for effective power management with multiple renewable sources is proposed $[5,6]$. The output of these multiple converters were fed to a common dc bus and then delivered to the load. These converters require more control strategies. In order to avoid multiple converters for multiple energy sources, new multiport converters (MPC) were designed. MPCs are classified based on i) port placement structures such as a)Multi Input Single Output (MISO), b) Single Input Multi Output (SIMO) and c) Multi Input Multi Output (MIMO)), ii)based on coupling (isolated and non-isolated) [7] iii)based on connections (series and parallel) and iv) based on conversion process (unidirectional and bidirectional).

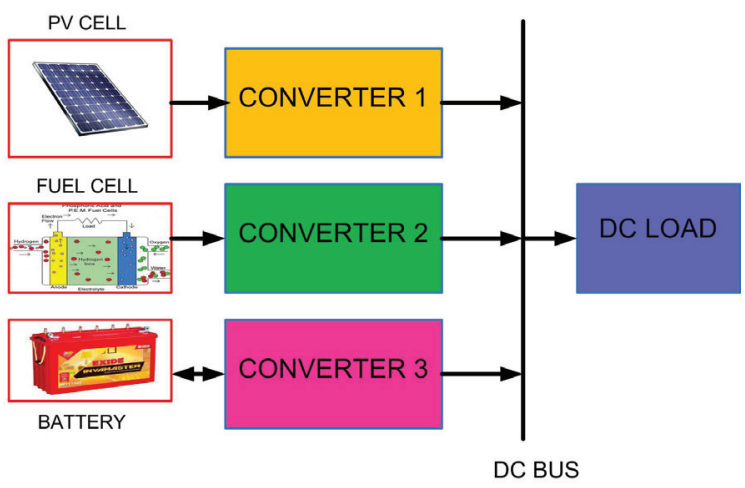

Figure 1: Conventional multi-input, multiple converters.

A systematic way of synthesizing multiport converter from a full bridge, bidirectional dc-dc converter is reported in $[8,9]$. Interesting topologies of multiport converters are derived by a combination of full bridge, half bridge/series resonant topologies via magnetic coupling using utility multi winding transformer [10-12]. Most of the literature focuses on the development of multiport converter (MPC) using traditional buck boost topology [13]. A three port converter with three active full bridges with three winding transformer is proposed in $[14,15]$ wherein two series resonance tanks added for reliable high frequency operation. The converter seemed to be bulky and hence three port bridge converters came into existence. In [16], cross coupling control strategy is investigated for a photovoltaic (PV) based three port dc-dc TAB (triple active bridge) converter. In [17], the author discussed different parallel circuit topologies. For multiple energy resources the multiport converter was then modified to multi-input single output (MISO) structure, that combines different sources at the input side and supplies a single output $[18,19]$. In single input multi output (SIMO), the outputs can be fed to different applications. In series topology, current in the weakest link blocks the current of the whole string [20], introduces high electrostatic potential and causes voltage sag problem [21]. So, parallel connected topologies are mostly preferred over series connected topologies.

Bidirectional power flow topologies were investigated for efficient power control. To allow bidirectional power flow and to integrate different sources, DC link and magnetic coupling inductors were incorporated in deriving multiport converters $[22,23]$. A high step up bidirectional converter with high voltage is discussed in $[24,25]$. Also, large number of electric vehicles connected to the grid affects the supply voltage quality.

Therefore, to meet the high current demand, bidirectional high-power three-phase three-port converter is designed for fast charging stations $[27,28]$. With increase in high voltage, high voltage ripples were also increased. So, in order to minimize the voltage ripple [26] an active clamping circuit is incorporated that increased the efficiency too. These multiport converters are designed both for off grid and on grid utility. Conventional grid systems are designed for specific power demand. In [29], a high frequency transformer is incorporated in an isolated multiport converter system for effective power flow management between high voltage dc transmissions (HVDC), networks in Electric aircraft (MEA) etc.

After extensive use of buck, boost, buck boost topologies, special converters such as Cuk, Zeta and Sepic converters came into existence. Comparative analyses of Cuk, Zeta, Sepic, Buck and Boost converters were performed [38]. Cuk converter gives a negative output voltage, while Sepic converter gives a positive output voltage but requires a continuous input current. Zeta converter gives a high voltage gain with lesser output voltage ripples. Owing to these disadvantages of Cuk and Sepic, Zeta converters are preferred for use in multiport converters for renewable energy applications because of compatibility. Zeta converter is a buck boost derived converter, where power factor correction is done. It is applied for LED lightings and welding purposes, but with low output power in [30,31]. [32] Explains that zeta converter takes maximum power from photovoltaic cells. A comparative analysis of boost and zeta converters have been dealt in $[33,34]$. Though iso- 
lated converters provide electrical galvanic isolation, they house more number of components resulting in large size. In [35], a deduction method is proposed which is based on a series of voltage balancers. Zeta converter was designed to feed a four phase switched reluctance motor whose input is from a PV source. Zeta converter and Landsman converter were integrated to form a multiport converter with different control circuits in [36]. This zeta converter also called as dual sepic converter is derived from a buck boost dc-dc converter to obtain a high voltage gain [37].The converter proved to show greater efficiency, but the disadvantages are that it uses more number of passive elements and is isolated. In order to rectify the issues cited in few of the above converters, a single stage non isolated power converter utilizing zeta converter has been designed in this paper.

\section{Multiport converter}

From the research on multiport converters, it has been observed that non isolated zeta converters have not been used so far. The zeta converter contributes in either increasing or decreasing the input voltage and also gives a low ripple output voltage that can be applied for applications that needs constant output voltage. This non isolated structure is compact with a single switch control. Depending on the advantages and feasibility of zeta, the multiport converter is designed as a zeta-zeta combination suitable for renewable input sources.

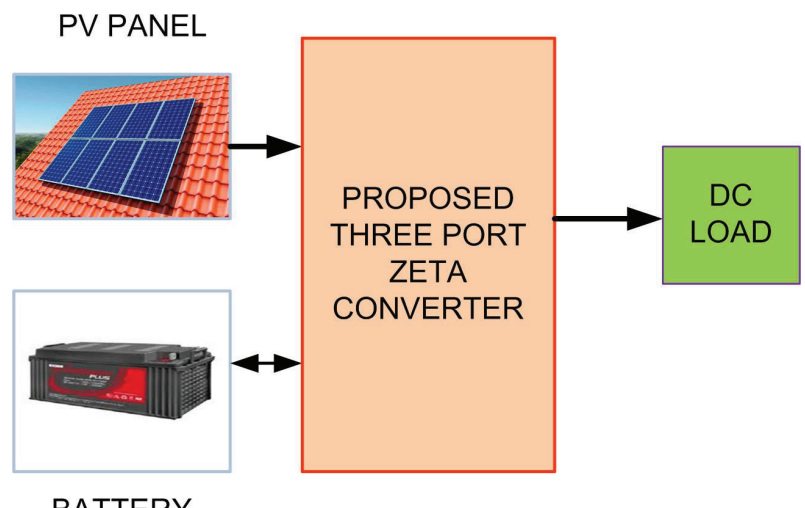

Figure 2: Proposed Zeta-Zeta Multiport converter

The primary focus of this paper is therefore to design a novel non isolated DC-DC converter based on zeta topology using DC link capacitors. This multiport converter (MPC) circuits accommodate one or more renewable input sources and a battery source. Based on the applications, the developed MPC can work as unidirectional or bi-directional circuit as shown in Figure2.
The zeta converter gives a high voltage gain with lesser output voltage ripples. Discontinuous input current can also be fed to the zeta converter.

The different operating modes of the three-port zeta converter have been analyzed. The circuit has been designed using small ripple approximation method. The simulation and hardware results have been shown in this paper.

\section{Proposed multiport zeta-zeta converter}

The Zeta converter shown in Figure 3 is a fourth order converter that has two capacitors $\left(C_{1}, C 2\right)$, two inductors $\left(L_{1}, L_{2}\right)$ which can step up and also step down the input voltage. It is used in power factor correction and regulation of voltages. It gives a non-

inverting output with a continuous input current [30]. The second order harmonic output voltage ripples are smaller.

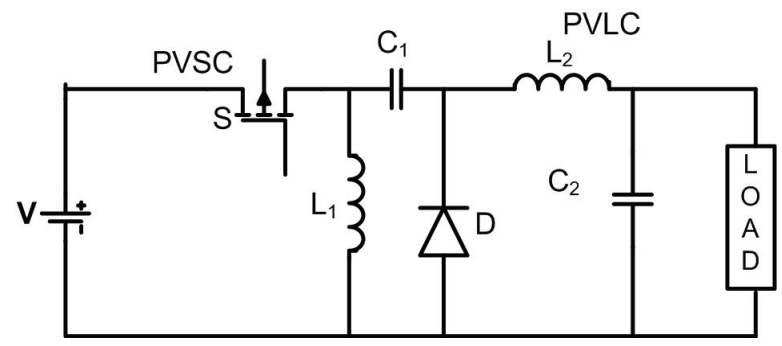

Figure 3: Basic Zeta converter circuit

Owing to the advantages of zeta, the proposed three port Dual Input Single Output (DISO) Zeta converter has been constructed by paralleling the basic structure.

In this paper, the basic Zeta structure is decomposed into two parts namely Pulsating Voltage Source Cell (PVSC) and Pulsating Voltage Load Cell (PVLC) to form a multiport converter, as shown in Figure 4. Two PVSCs have been developed from two basic zeta converters and coupled with PVLC in the proposed circuit.

Two topologies of multiport converters (unidirectional and bidirectional) are presented. Three ports are designed here, which can further be increased to ' $n$ ' number of ports.

\subsection{Operation and Control Approach}

The three-port zeta converter presented in Figure 4 has two input ports and one output port. The three-port zeta converter is provided with a photovoltaic source along 


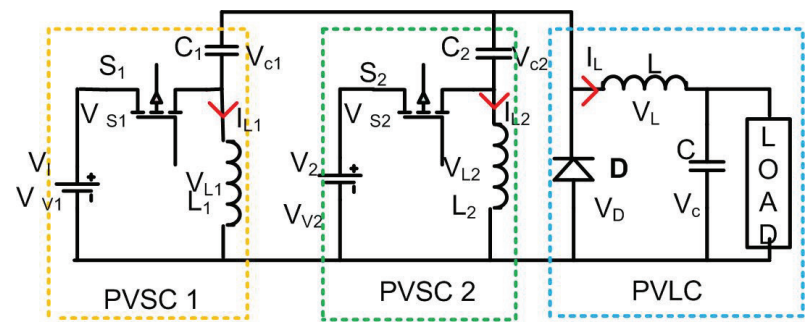

Figure 4: Non isolated three port zeta converter

with a battery backup or with a rectified input source from wind or with a fuel cell. Depending upon the available inputs, the converter works in unidirectional mode as shown in Figure 4 and in bidirectional mode as shown in Figure 8. Both topologies have been explained as topology 1 (unidirectional) and topology 2(bidirectional).

\subsubsection{Topology 1: Three Port zeta as unidirectional con-} verter

To understand the operation, assume the converter is interfaced with a PV source and a rectified input from a

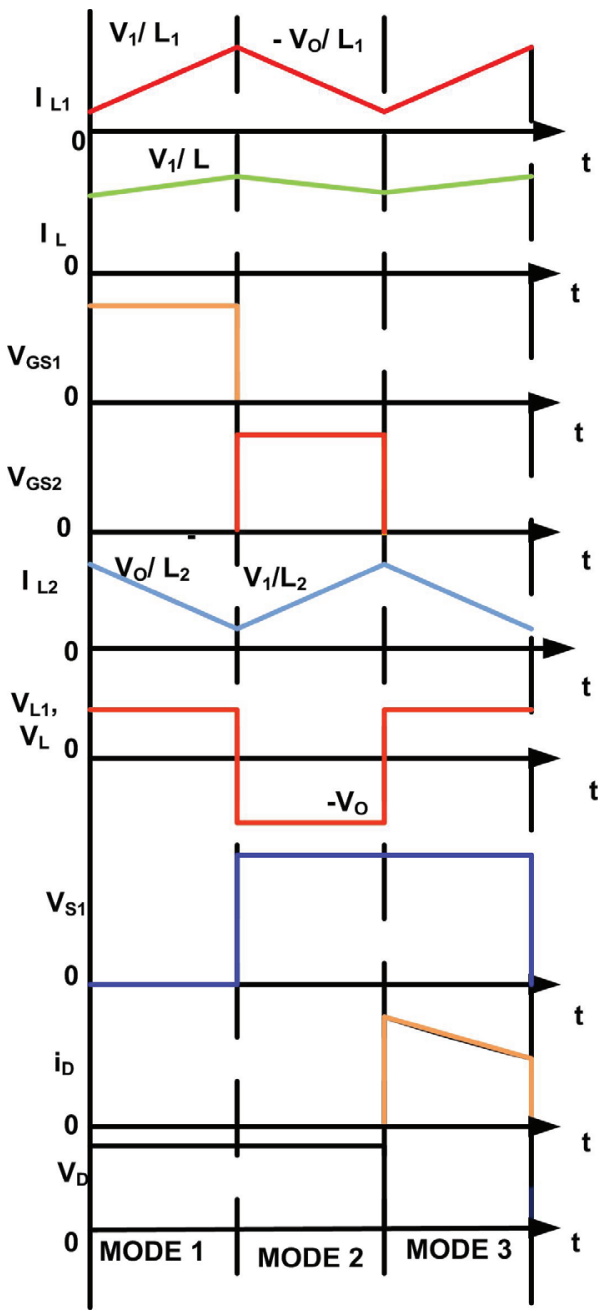

Figure 5: Key waveforms for Topology 1, when the converter is operating in unidirectional mode wind energy system. Let the input voltage from source 1 be $V_{1}$ and source 2 be $V_{2}$ with duty cycles $D_{1}$ and $D_{2}$ respectively. With the same voltage and duty cycles, the converter acts like an individual zeta converter and supply power simultaneously.

The key waveforms of the three-port zeta-zeta converter operating in continuous conduction mode are depicted in Figure 5. The waveforms of the current through the inductors, voltage across the switches $S_{1}$ and $S_{2}$ current through the diode, voltage across the inductors are shown when the converter is operating in unidirectional mode.

If $\mathrm{V}_{1}=\mathrm{V}_{2}=\mathrm{V}$, the output voltage expression will be,

$\mathrm{Vo}_{\mathrm{o}}=\frac{\mathrm{DV}}{1-\mathrm{D}}$

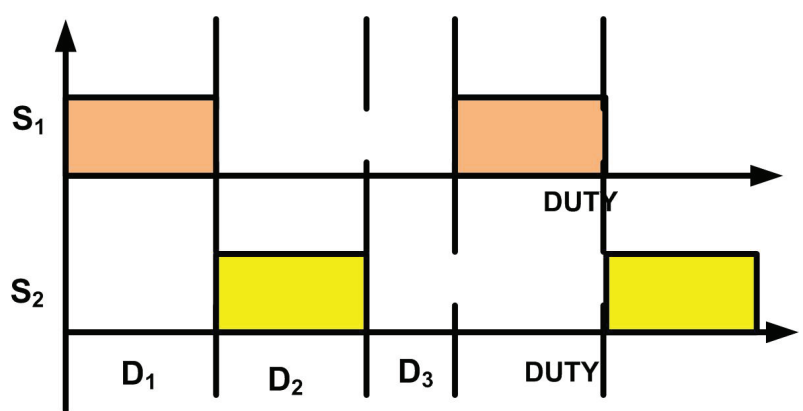

Figure 6: Operating modes of the proposed converter

Assuming $\mathrm{V}_{1}>\mathrm{V}_{2}$ and $\mathrm{D}_{2}>\mathrm{D}_{1},\left(\mathrm{D}_{1}\right.$ and $\mathrm{D}_{2}$ - duty cycles) as given in Figure 6 , there are three modes of operations that are explained below:

Mode-1 ( $\mathrm{S}_{1}$ on, $\mathrm{S}_{2}$ off): The equivalent circuit of mode 1 is shown in Figure $7 a$. In mode 1 , as $V_{1}$ is greater than $V_{2}, S_{1}$ is switched ON and switch $S_{2}$ is switched OFF, the output voltage across $\mathrm{R}$ load is contributed by $\mathrm{V}_{1}$ only. When $S_{1}$ is closed, inductor $L_{1}$ gets charged by $V_{1}$. The capacitor $C_{1}$ is assumed to be pre-charged. It later discharges along the inductor $L$ and load.

Applying the concept of voltage-second balance on inductors and charge balance on capacitors, the follow-

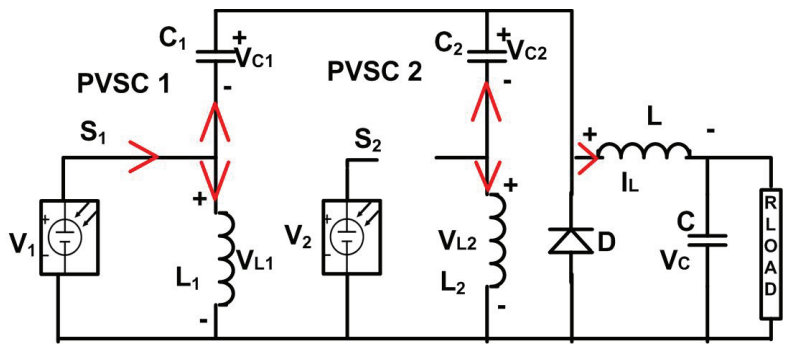

Figure 7a: When PVSC 1 feeds the load 
ing expressions have been developed. Let " $\mathrm{T}_{\mathrm{s}}$ "-be the total conducting time of the switch.

$$
\begin{aligned}
& \mathrm{V}_{1}=\mathrm{V}_{\mathrm{L} 1} \\
& \mathrm{~V}_{1}+\mathrm{V}_{\mathrm{C} 1}-\mathrm{V}_{\mathrm{C} 2}=\mathrm{V}_{\mathrm{L} 2} \\
& \mathrm{I}_{\mathrm{C}}=\mathrm{I}_{\mathrm{L}}-\frac{\mathrm{V}_{\mathrm{o}}}{\mathrm{R}}
\end{aligned}
$$

Mode-2 ( $S_{1}$ off, $S_{2}$ on): After a duty cycle of $D_{1}$, switch $S_{1}$ is switched off and instantly switch $\mathrm{S}_{2}$ is closed (mode2). So $V_{2}$ starts supplying the load (Figure 7.b)

$$
\begin{aligned}
& \mathrm{V}_{2}=\mathrm{V}_{\mathrm{L} 2} \\
& \mathrm{~V}_{2}+\mathrm{V}_{\mathrm{C} 2}-\mathrm{V}_{\mathrm{C} 1}=\mathrm{V}_{\mathrm{L} 1}
\end{aligned}
$$

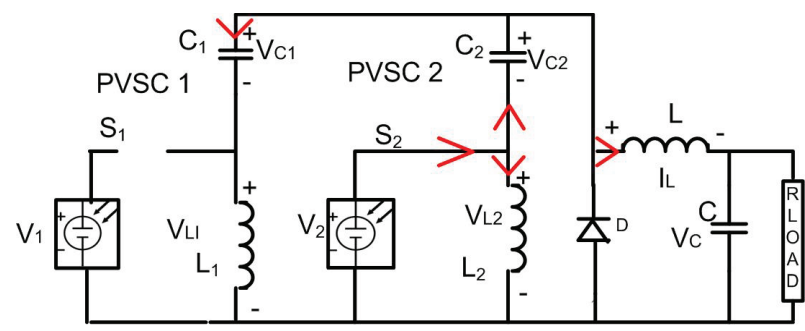

Figure 7b: When PVSC 2 feeds the load

Mode-3 $\left(\mathrm{S}_{1}\right.$ and $\mathrm{S}_{2}$ off): When both switches are open, the charge stored in the inductors will support the conduction. Now the diode is forward biased and acts as a closed switch allowing current to move from its anode towards cathode as shown in Figure 7.c.

$$
\begin{aligned}
& \mathrm{V}_{\mathrm{L} 1}=\mathrm{V}_{\mathrm{C} 1} \\
& \mathrm{~V}_{\mathrm{L}}=\mathrm{V}_{0}
\end{aligned}
$$

Assuming $\mathrm{V}_{\mathrm{C} 1}=\mathrm{V}_{\mathrm{C} 2}$,

Equation (9) has been framed by applying the voltagesecond balance to inductors and charge balance on capacitors.

$$
\begin{aligned}
& \int_{0}^{\mathrm{T}_{\mathrm{s}}} \mathrm{V}_{\mathrm{L} 2}(\mathrm{t}) \mathrm{dt}=\left(\mathrm{V}_{1}+\mathrm{V}_{\mathrm{C} 1}-\mathrm{V}_{0}\right) \mathrm{D}_{1} \mathrm{~T}_{\mathrm{s}}+ \\
& +\left(\mathrm{V}_{2}+\mathrm{V}_{\mathrm{C} 2}-\mathrm{V}_{0}\right) \mathrm{D}_{2} \mathrm{~T}_{\mathrm{s}}+\mathrm{V}_{0}\left[1-\left(\mathrm{D}_{1}+\mathrm{D}_{2}\right)\right]=0 \\
& \mathrm{Vo}_{0}=\frac{\left(\mathrm{V}_{1}-\frac{\mathrm{V}_{1} \mathrm{D}_{1}+\mathrm{V}_{2} \mathrm{D}_{2}}{1-\left(\mathrm{D}_{1}+\mathrm{D}_{2)}\right.}\right) \mathrm{D}_{1}+\left(\mathrm{V}_{2}-\frac{\mathrm{V}_{1} \mathrm{D}_{1}+\mathrm{V}_{2} \mathrm{D}_{2}}{1-\left(\mathrm{D}_{1}+\mathrm{D}_{2}\right)}\right) \mathrm{D}_{2}}{\mathrm{D}_{1}+\mathrm{D}_{2}-\left(1-\left(\mathrm{D}_{1}+\mathrm{D}_{2}\right)\right)}
\end{aligned}
$$

So the capacitor $C_{1}$ gets charged by the inductor $L_{1}$ and $C_{2}$ gets charged by inductor $L_{2}$. In topology 1 , since both sources are renewable energy resources, the converter behaves as unidirectional converter and the flow of energy is from source to load.

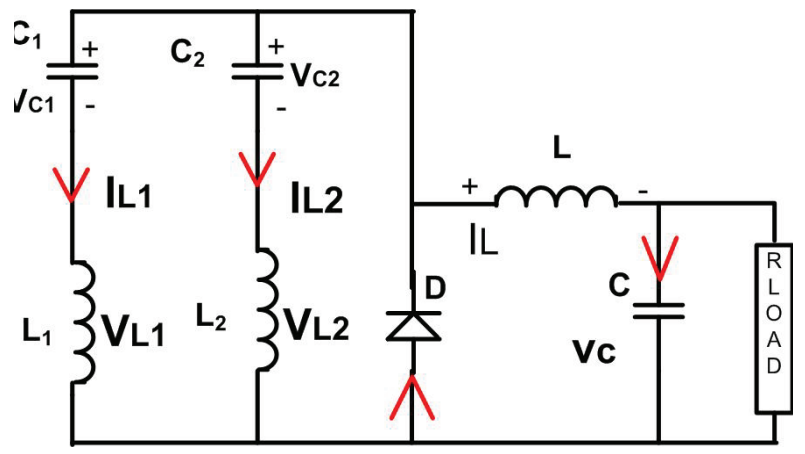

Figure 7c: When both $\mathrm{S}_{1}$ and $\mathrm{S}_{2}$ are OFF

3.1.2 Topology 2: Three Port zeta as bidirectional converter To analyze the working, the proposed three port bidirectional Zeta converter is reconstructed with an additional switch $\mathrm{S}_{3}$ as shown in Figure 8.The first input port is connected to a PV source and the second is connected to a battery whereas the output port is connected to the load.

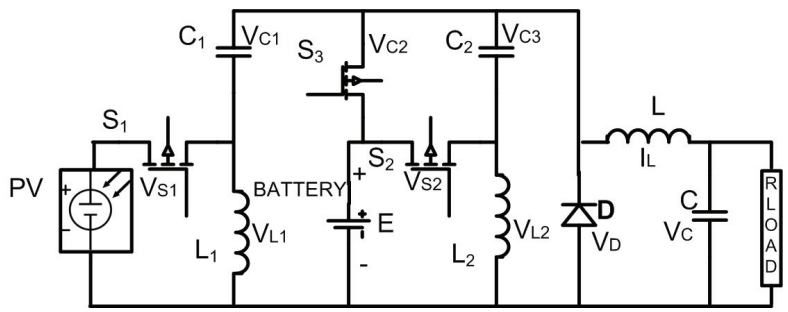

Figure 8: Three Port bidirectional Zeta converter-Topology 2

The energy transfer in this converter can be explained in four ways

1) From PV Source to load

2) From PV Source to battery and load

3) From battery to load

4) From load to battery.

After harvesting maximum power from PV source, it is interfaced to the load via a dc link capacitor. Any unbalancing that occurs during integration will be controlled by charging and discharging action of the battery. Here the switches $\mathrm{S}_{2}$ and $\mathrm{S}_{3}$ complement each other. For charging the battery, $\mathrm{S}_{3}$ is to be turned $\mathrm{ON}$ and corresponding $\mathrm{S}_{2}$ is OFF. In case of back EMF, all the PVSCs are turned off and only $S_{3}$ is turned on. The operation of integrated power system has four possible operating modes which are consolidated in Table 1. Here " $E$ " is the voltage across the battery.

Mode 1: When $V>E$, battery charges through switch $\mathrm{S}_{3}$ and the (source1) PV supplies power to the load. We can say that the converter acts as a partial bidirectional converter in Single Input Dual Output (SIDO) mode as in Figure 9a. 


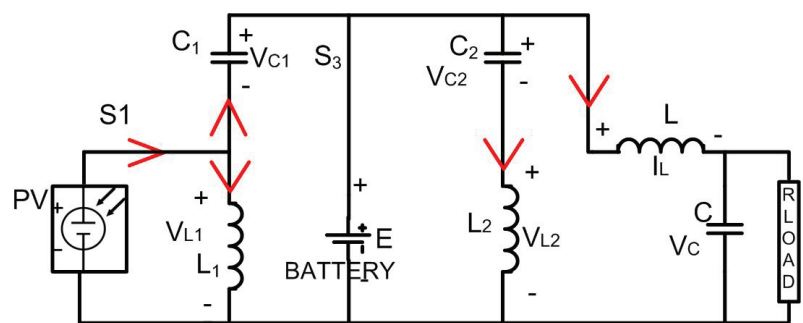

Figure 9a: When $\mathrm{V}>\mathrm{E}, \mathrm{S}_{1}$ and $\mathrm{S}_{3}$ are $\mathrm{ON}, \mathrm{S}_{2}$ is OFF

Mode 2: When $\mathrm{V}<\mathrm{E}$, battery discharges through switch $\mathrm{S}_{3}$ as in Figure 9.b and the load receives power from the battery and the converter operates in SISO mode.

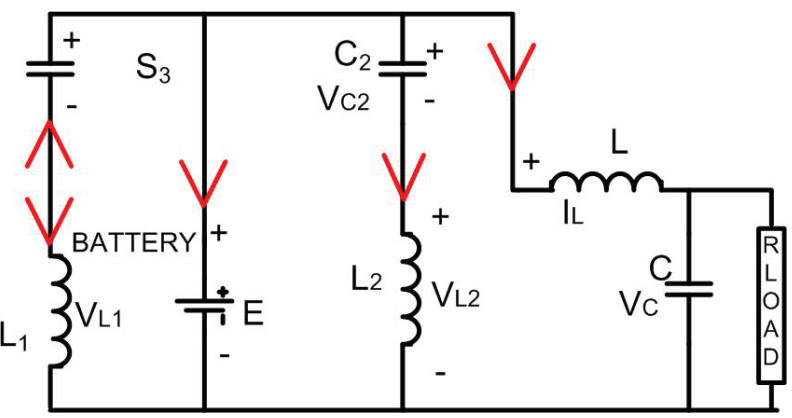

Figure $9 b: V<E, S_{1}$ and $S_{2}$ are $O F F, S_{3}$ is $O N$

Mode 3: When $\mathrm{V}=\mathrm{E}$, the load receives power from the PV and battery. The converter operates in Dual Input Single Output (DISO) mode as shown in Figure 9c.

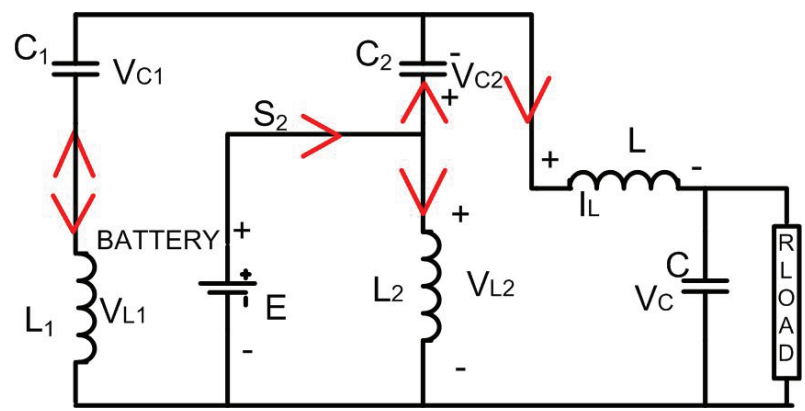

Figure 9c: When $\mathrm{V}=\mathrm{E}, \mathrm{S}_{2}$ is $\mathrm{ON}, \mathrm{S}_{1}$ and $\mathrm{S}_{3}$ are OFF

Mode 4: When $\mathrm{V}=0$ and $\mathrm{E}<$ state of charge (SOC), the load supplies power by the charging action of the battery through switch $\mathrm{S}_{2}$. The converter in Figure $9 \mathrm{~d}$ operates as a bidirectional converter in SISO mode.

With respect to the operating modes, the equivalent circuit for each mode is developed as shown from Figure 9.a to Figure 9.d. When PV voltage is greater than or equal to battery, PV will be supplying the load. Table 1 shows the different modes of operation of PV and battery.

The steady state equations of the converter are as follows.

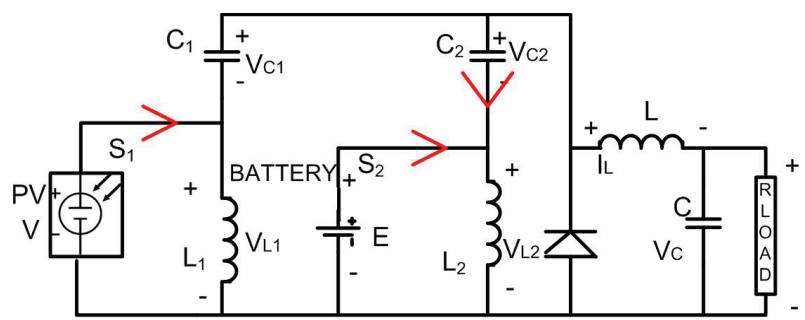

Figure 9d: When $\mathrm{V}=0, \mathrm{~S}_{1}$ and $\mathrm{S}_{2}$ are $\mathrm{ON}, \mathrm{S}_{3}$ is $\mathrm{OFF}$

Table 1: Different Modes of Operation of PV and Battery

\begin{tabular}{|c|c|c|c|}
\hline Mode & $\begin{array}{l}\text { Switch } \\
\text { Status }\end{array}$ & $\begin{array}{l}\text { Source1 } \\
\text { (PV) }\end{array}$ & $\begin{array}{l}\text { Source } 2 \\
\text { (Battery) }\end{array}$ \\
\hline$V>E$ & $\begin{array}{c}\mathrm{S}_{1} \text { and } \mathrm{S}_{3} \\
\text { are ON and } \\
\mathrm{S}_{2} \text { is OFF }\end{array}$ & $\begin{array}{l}\text { Supplies } \\
\text { power to } \\
\text { load }\end{array}$ & Charges \\
\hline $\mathrm{V}<\mathrm{E}$ & $\begin{array}{c}\mathrm{S}_{3} \text { is } \mathrm{ON} \\
\text { and } \mathrm{S}_{1}, \mathrm{~S}_{2} \\
\text { are OFF }\end{array}$ & - & Discharges \\
\hline$V=E$ & $\begin{array}{c}\mathrm{S}_{1} \text { and } \mathrm{S}_{3} \\
\text { are } \mathrm{OFF} \\
\text { and } \mathrm{S}_{2} \text { is } \\
\mathrm{ON}\end{array}$ & $\begin{array}{c}\text { Supplies } \\
\text { power to } \\
\text { load }\end{array}$ & $\begin{array}{c}\text { Discharges } \\
\text { and } \\
\text { Supplies } \\
\text { power to } \\
\text { load }\end{array}$ \\
\hline $\begin{array}{c}\mathrm{V}=0 \text { and } \\
\mathrm{E}<\mathrm{SOC}\end{array}$ & $\begin{array}{c}\mathrm{S}_{1} \text { and } \mathrm{S}_{2} \\
\text { are ON and } \\
\mathrm{S}_{3} \text { is OFF }\end{array}$ & - & $\begin{array}{l}\text { Charges } \\
\text { due to EMF } \\
\text { present in } \\
\text { the load }\end{array}$ \\
\hline
\end{tabular}

When battery is charging:

When both $\mathrm{S}_{1}$ and $\mathrm{S}_{3}$ are $\mathrm{ON}$

$$
\begin{aligned}
& \mathrm{V}_{1}+\mathrm{V}_{\mathrm{C} 1}-\mathrm{V}_{\mathrm{C} 2}=\mathrm{V}_{\mathrm{L} 2} \\
& \mathrm{~V}_{1}+\mathrm{V}_{\mathrm{C} 1}-\mathrm{V}_{0}=\mathrm{V}_{\mathrm{L}}
\end{aligned}
$$

When battery is discharging:

When both $\mathrm{S}_{1}$ and $\mathrm{S}_{3}$ are OFF, $\mathrm{S}_{2}$ is $\mathrm{ON}$

$$
\mathrm{V}_{1}+\mathrm{V}_{\mathrm{C} 2}-\mathrm{V}_{0}=\mathrm{V}_{2}
$$

When $\mathrm{S}_{1}$ and $\mathrm{S}_{2}$ are $\mathrm{ON}$ and $\mathrm{S}_{3}$ is OFF

$$
\begin{aligned}
& \mathrm{V}_{\mathrm{C} 1}=\mathrm{V}_{\mathrm{L} 1} \\
& \mathrm{~V}_{\mathrm{C} 2}=\mathrm{V}_{\mathrm{L} 2}
\end{aligned}
$$

Applying the voltage-second balance inductors and charge balance on capacitors

$$
\mathrm{V}_{0}=\frac{\mathrm{V}_{1} \mathrm{D}_{1}-\frac{\mathrm{V}_{1} \mathrm{D}_{1}^{2}}{1-\mathrm{D}_{1}}}{2 \mathrm{D}_{1}-1}
$$




\subsection{Determination of circuit parameters:}

For the converter in CCM, the ripple voltage should be kept at minimum value. Applying the concept of small ripple approximation, the expressions of $L_{1}, L_{2^{\prime}} L, C_{1}, C_{2^{\prime}}$ and $\mathrm{C}$ with reference to current and voltage ripples are derived. In mode 1 and mode 2 the current of the inductor increases from a lower level to higher level, say $\mathrm{I}_{\mathrm{L} 11}$ to $\mathrm{I}_{\mathrm{L} 12}$ and in next mode, the current drops from $\mathrm{I}_{\mathrm{L} 11}$ to $I_{L 12}$. So, the current ripple is observed to be

$$
\begin{aligned}
& \Delta I_{L 1}=I_{L 12}-I_{L 11}, \mathrm{f}-\text { frequency } \\
& L_{1} \frac{d i_{L 1}}{d t}=V_{1}+V_{2}
\end{aligned}
$$

$f=1 / T$ where $T$ is the total switching time period.

$$
\Delta I_{L 1}=\frac{\left(V_{1}+V_{2}\right)\left(D_{1}+D_{2}\right)}{f L_{1}}
$$

Assuming $L_{2}$ is charged linearly during the period $t_{2}$ and $t_{3}$ from $I_{L 21}$ and $I_{L 22}$, the inductor current ripple is

$$
\Delta I_{L 2}=\frac{\left(V_{1}+V_{2}\right)\left(D_{1}+D_{2}\right)}{f L_{2}}
$$

The values of inductors and capacitors are obtained from the following equations

$$
\begin{aligned}
& L_{1}=\frac{\left(V_{1}+V_{2}\right)\left(D_{1}+D_{2}\right)}{f \Delta I_{L 1}} \\
& L_{2}=\frac{\left(V_{1}+V_{2}\right)\left(D_{1}+D_{2}\right)}{f \Delta I_{L 2}} \\
& C_{1}=\frac{I_{L 1}\left(1-D_{1}\right)}{f \Delta V_{C 1}} \\
& C_{2}=\frac{I_{L 2}\left(D_{1}+D_{2}\right)}{f \Delta V_{C 2}}
\end{aligned}
$$

\section{Simulation and experimental results}

\subsection{Simulation:}

The simulation model of the non-isolated zeta-zeta converter is developed with the help of MATLAB Simulink. The simulation results of the converter operating in CCM are shown in Figure 10.a and Figure 10.b. These waveforms were observed when the converter was operated in unidirectional topology.ie only switches $S_{1}$ and $\mathrm{S}_{2}$ are turned on and switch $\mathrm{S}_{3}$ remains off. The current flows only from source to the load in unidirectional mode of operation. The voltage across the switches $S_{1}$ and $S_{2}$ varies with change in duty cycles. The inductor currents $\mathrm{I}_{\mathrm{L} 1}$ and $\mathrm{I}_{\mathrm{L} 2}$ prove that the converter is operated in CCM mode and shows variations in time graph. The converter was simulated with the parameters as follows: $L_{1}$ and $L_{2}$ with $33 \mathrm{mH}, C_{1}$ and $C_{2}$ with $100 \mu \mathrm{F}$. The filter inductor $L_{3}=1000 \mu \mathrm{H}$ and filter capacitor $C_{3}=140 \mu \mathrm{F}$. The inductor currents $I_{L_{1}}$ and $I_{L_{2}}$ prove that the converter is operated in CCM mode and shows variations in time graph. Also, the variations of charging and discharging voltages across capacitors $C_{1}$ and $C_{2}$ are shown in the plot. The simulation results of the converter operating in CCM are shown in Figure 10.a and Figure 10.b.
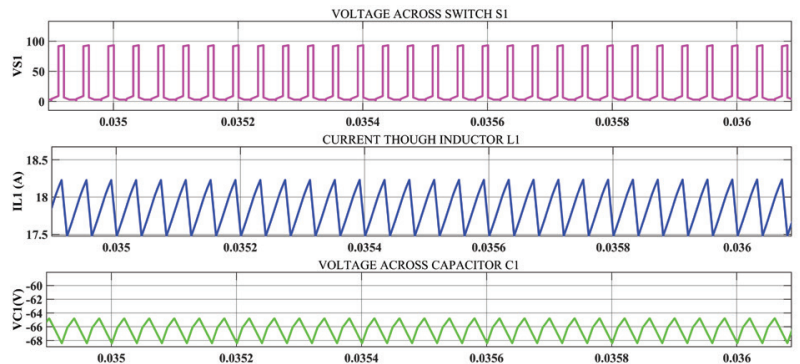

Figure 10a: Waveforms when PVSC1 supplies
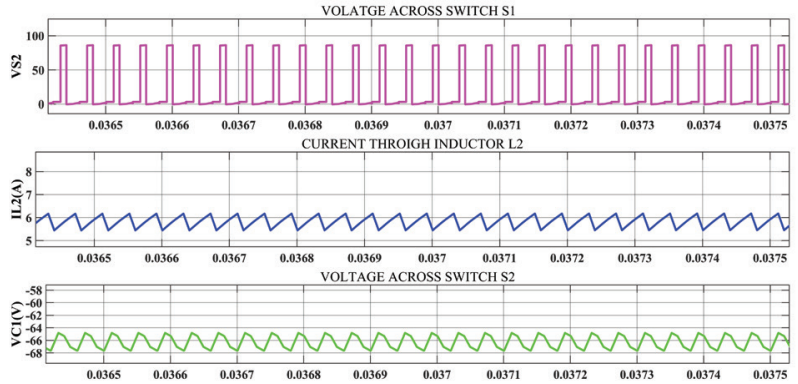

Figure 10b: Waveforms when PVSC2 supplies

These waveforms were observed when the converter was operated in unidirectional topology (only switches $\mathrm{S}_{1}$ and $\mathrm{S}_{2}$ are turned on and switch $\mathrm{S}_{3}$ remains turned off). With duty cycles $\mathrm{D}_{1}=30 \%$ and $\mathrm{D}_{2}=50 \%$, the converter boosts the input voltages, $\mathrm{V}_{1}=\mathrm{V}_{2}=20 \mathrm{~V}$ to $\mathrm{V}_{\mathrm{O}}=60.73 \mathrm{~V}$ and $I_{0}=1.084 \mathrm{~A}$ at $\mathrm{R}=42 \Omega$. The output voltage and output current waveforms are depicted in Figure 11.

During turn on process of switches $S_{1}$ and $S_{3}$, the battery charges from the initial state of charge as shown in Figure 12. The initial state of charge (SOC) is taken as $5 \%$. From the waveforms of battery parameters, the battery is charging in this case, as the SOC is increasing in nature. Therefore, when supply voltage is greater than the battery EMF, Source 1 (PV) supplies power to the load. 


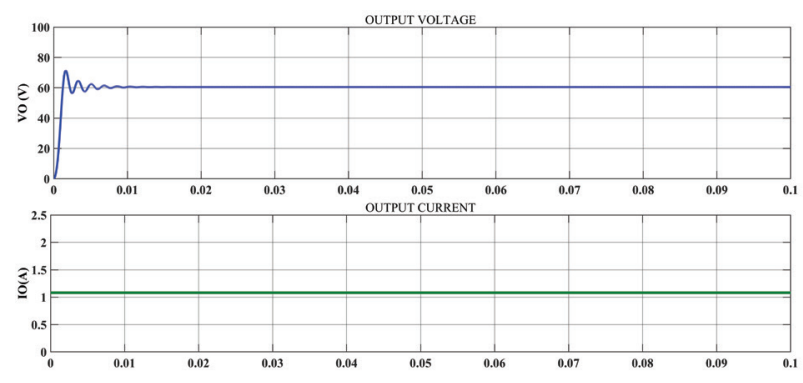

Figure 11: Output voltage and output current waveforms.

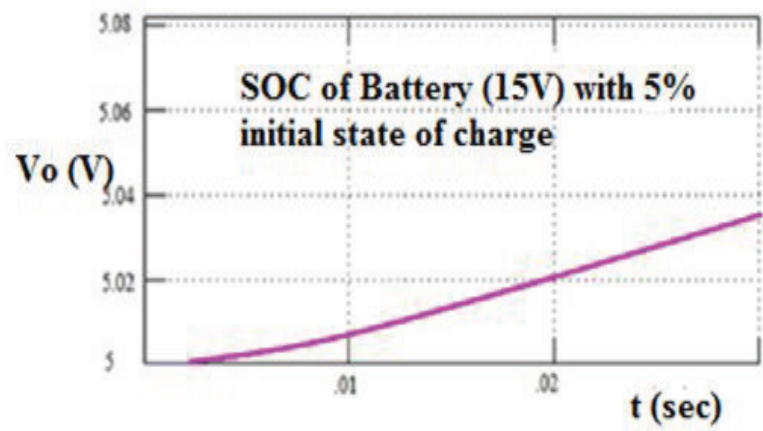

Figure 12: State of charge (SOC) of battery while charging

Figure 13, shows the MATLAB simulink outputs obtained for an input voltage of $\mathrm{V}_{1}=25 \mathrm{~V}$ and the boosted output voltage is $V_{0}=42 \mathrm{~V}$ for a duty cycle of $70 \%$., obtained across an output load resistor of $10 \Omega$.

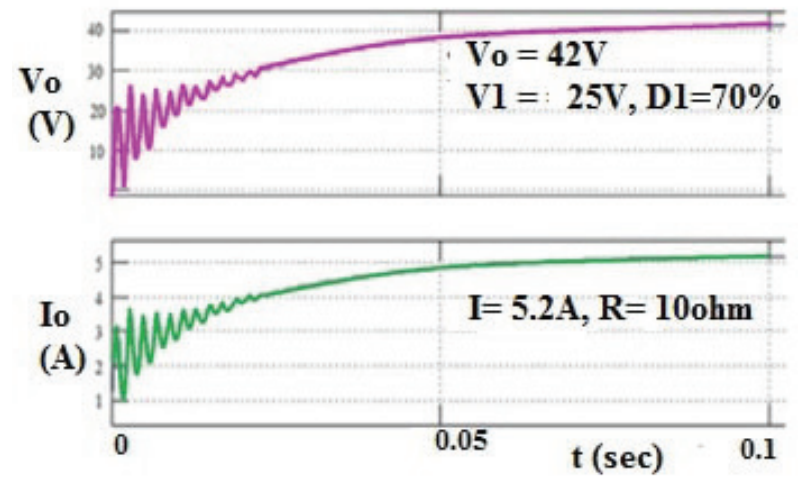

Figure 13: Output voltage and current when battery is charging.

As soon as switch $\mathrm{S}_{2}$ is closed, the current through inductor and voltage across the capacitor increases due to discharging action of the battery as shown in Figure14.

When $\mathrm{E}>\mathrm{V}$, the battery which has charged in the previous cycle discharges and gives power to load which is shown in Figure 15.

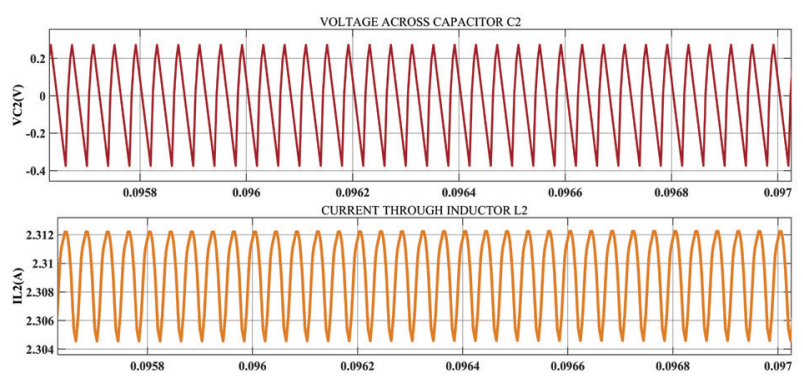

Figure 14: Inductor currents and capacitor voltages in bidirectional converter when battery is discharging

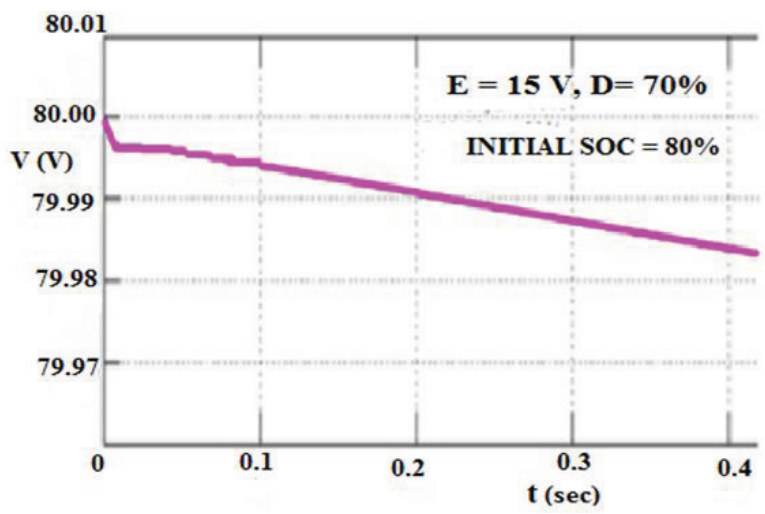

Figure 15: State of charge of battery while discharging.

The initial state of charge (SOC) is taken as $80 \%$. From the waveforms of battery parameters, it is clear that the battery is discharging in this case, as the SOC is decreasing in nature.

The measured output voltage, Vo(actual) from the simulink model are cross-verified with the estimated output voltage Vo(estimated) for different sets of voltage inputs $\left(V_{1}, V_{2}\right)$ along with duty cycles $\left(D_{1}, D_{2}\right)$ and are tabulated in Table 2 and Table 3.

Table 2: Actual Values and Estimated Values of Output Voltage for different supply Voltages

\begin{tabular}{|c|c|c|c|c|c|}
\hline $\begin{array}{c}V_{1} \\
(V)\end{array}$ & $V_{2}(V)$ & $\begin{array}{c}D_{1} \\
(\%)\end{array}$ & $\begin{array}{c}D_{2} \\
(\%)\end{array}$ & $\begin{array}{c}V_{0}(V) \\
\text { (actual) }\end{array}$ & $\begin{array}{c}\text { Vo (V) } \\
\text { (estimated) }\end{array}$ \\
\hline 24 & 12 & 30 & 40 & 37 & 40 \\
\hline 30 & 15 & 30 & 50 & 75 & 82.5 \\
\hline 20 & 20 & 30 & 50 & 63 & 65 \\
\hline 25 & 20 & 30 & 40 & 48.5 & 51 \\
\hline 30 & 20 & 30 & 50 & 90 & 93 \\
\hline 36 & 24 & 30 & 40 & 65 & 68 \\
\hline 36 & 24 & 30 & 50 & 109 & 112.5 \\
\hline
\end{tabular}


Table 3: Actual Values and Estimated Values of Output Voltage when the Battery is charging

\begin{tabular}{|c|c|c|c|c|}
\hline$V_{1}(V)$ & $E(V)$ & $D(\%)$ & $\begin{array}{c}\text { Vo }(V) \\
\text { (actual) }\end{array}$ & $\begin{array}{c}\text { Vo }(V) \\
\text { (estimated) }\end{array}$ \\
\hline 24 & 12 & 30 & 8 & 10.28 \\
\hline 30 & 15 & 30 & 11 & 12.85 \\
\hline 25 & 20 & 30 & 10.5 & 10.7 \\
\hline
\end{tabular}

The results in the tables above further helps in plotting voltage gain and regulation curves. The estimated and actual values were compared.

\subsection{Design of controller for the proposed zeta-zeta converter:}

The intention of controlling a converter is to maintain a constant output voltage on the load side. Hence a closed loop feedback controller has been provided in the three-port zeta converter circuit. This is such that it feeds the dc load with constant output voltage with low ripple. Figure 16 shows the block diagram of the closed loop controller used for controlling the switches in the multiport converter.

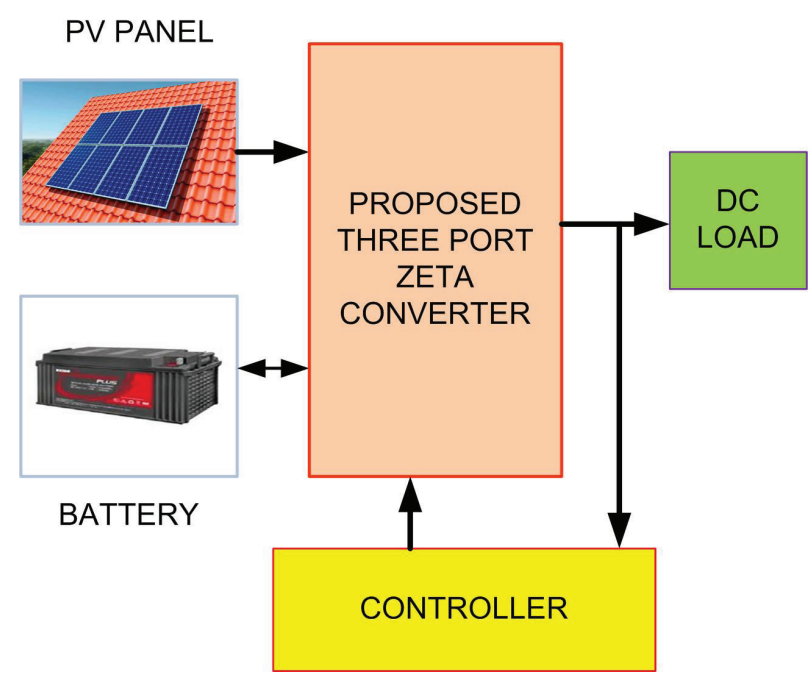

Figure 16: Block diagram of the multiport converter with controller

Small-Signal model of the controller:

When the converter is operating in continuous conduction mode, the circuit is realized in two modes. They are when the MOSFET turns on, it is in charging mode and when the MOSFET turns off, it is in discharging mode. In order to design a suitable controller for this system, a small signal model is developed using state-space averaging (SSA) technique.
The state space equations are given by

$$
\begin{aligned}
& \frac{\mathrm{dx}(\mathrm{t})}{\mathrm{dt}}=\mathrm{Ax}(\mathrm{t})+\mathrm{Bu}(\mathrm{t}) \\
& \mathrm{y}(\mathrm{t})=\mathrm{Cx}(\mathrm{t})+\mathrm{Eu}(\mathrm{t})
\end{aligned}
$$

Where $A$ is the system matrix, $B$ is the control matrix, $C$ is the output matrix and $E$ is the identity matrix. On perturbation, the steady state solution for the proposed converter can be determined from the above equations resulting in

$$
\begin{aligned}
& X=-A^{-1} B U \\
& Y=\left(-C^{-1} B+E\right) U
\end{aligned}
$$

Where $\mathrm{X}$ is the state vector, $\mathrm{U}$ is the control vector and $\mathrm{Y}$ is the output vector.

The transfer functions of the closed loop controller system are derived by using SSA method.

i) The voltage gain of the zeta-zeta converter (when PV is supplied):

$$
\begin{aligned}
\operatorname{Vo}(\mathrm{s}) / \operatorname{Vin}(\mathrm{s})= & \left(\left(4 x[10) \wedge 6\left(\mathrm{~s}^{\wedge} 2+(10) \wedge 6\right)\right) /\right. \\
& \left(\mathrm{s}^{\wedge} 2+20.1 \mathrm{~s}+1.208 \mathrm{x}(10) \wedge 5\right) \\
& \left.\left(\mathrm{s}^{\wedge} 2+29.9 \mathrm{~s}+8.279 \mathrm{x}(10) \wedge 6\right)\right)
\end{aligned}
$$

ii) The voltage gain of the zeta-zeta converter (when battery is supplied):

$$
\frac{\operatorname{Vo}(s)}{\operatorname{Vin}(s)}=\frac{6.5 \times 10^{6}}{\left(s^{2}+50 s+5 \times 10^{6}\right)}
$$

The transient state of the converter can now be determined using these transfer function relations. Since PV is used as input, the output voltage may vary with respect to the input. Hence PI Controller has been designed for the multiport converter in order to maintain a constant output voltage. This closed loop control system has been performed in MATLAB environment. The proportional gain constant $\mathrm{K}_{\mathrm{p}}$ and integral constant $\mathrm{K}_{\mathrm{I}}$ were obtained by Zeigler-Nichols PI tuning method. The $\mathrm{K}_{\mathrm{p}}$ was taken as 100 and $\mathrm{K}_{1}$ as 0.1 in the PI controller.

A constant output voltage of $61 \mathrm{~V}$ was obtained for an input voltage of 20V. When there is a change in load, the voltage slightly changes from one state to another, but still resumes the same constant output voltage of $61 \mathrm{~V}$. This change is known as transient as shown in Figure 17. 


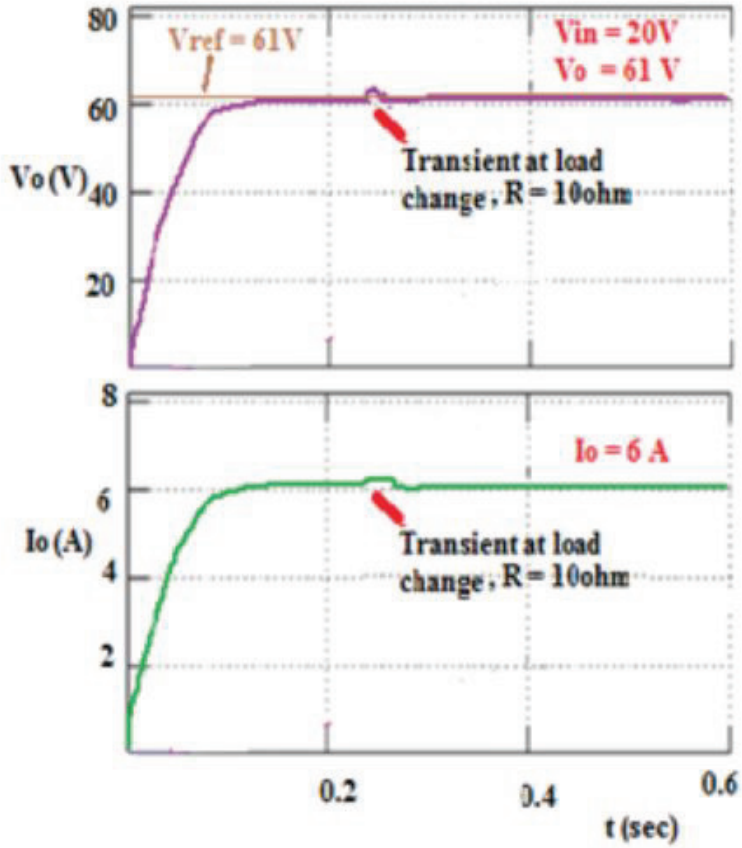

Figure 17: Simulated Output voltage and output current waveforms of closed loop converter.

A reference voltage of $61 \mathrm{~V}$ was set in the controller. The output voltage was observed as $61 \mathrm{~V}$ for a $15 \Omega$ load resistor. When the load was varied to $10 \Omega$, there was a small transient (at $t=0.25 \mathrm{sec}$ ) in the output voltage and output current. But the output voltage and current were maintained at the same constant values due to the action of the controller as depicted in Figure 17. The peak overshoot during open loop is $23 \%$ and it is $1.6 \%$ in closed loop. The steady state error has also been reduced to 0.01 . In case of load changes, the multiport converter delivers a constant output voltage. Thus the use of controller results in constant output voltage.

The proposed zeta-zeta converter was simulated using MATLAB Simulink environment. The waveforms of voltage across the switches $S_{1}, S_{2}$, inductor currents and capacitor voltages are shown. When both sources are supplied with $20 \mathrm{~V}$ input, the converter boosts to $61 \mathrm{~V}$ output voltage and 6.29A output current, with 30\% and $50 \%$ duty cycles. When PV voltage is greater than the battery voltage, then PV will supply the load. The initial SOC for charging is $5 \%$ and for discharging it is $80 \%$. From tables 3 and 4 , the simulated values are closer to the estimated values of output voltages.

\subsection{Hardware results}

To illustrate the performance, a prototype model of bidirectional three port zeta converters, controlled by dSPACE real time controller is built with the specified parameters. The hardware set up is as presented in Figure 18.a and Figure 18.b. The power stage of this system consists of three port zeta topology with a load resistance of $50 \mathrm{Ohms}$. Switching devices IRFP 450 MOSFETs with switching frequency $38 \mathrm{kHz}$ act as switches $\mathrm{S}_{1}, \mathrm{~S}_{2}$ and $\mathrm{S}_{3}$.

The view of the proposed multiport zeta-zeta converter is clearly shown in the hardware circuit of Figure 18a. The output voltage is shown in a closer view. Figure $18 \mathrm{~b}$ shows the complete hardware set up of the proposed converter with dSPACE controller.

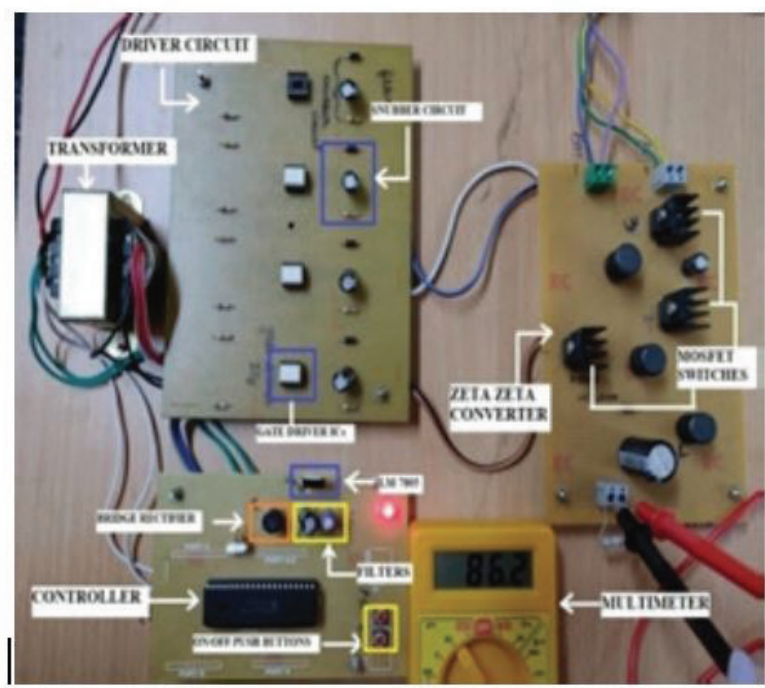

Figure 18a: Zeta-Zeta Hardware prototype

In this zeta-zeta converter prototype we have three MOSFET switches $\left(S_{1}, S_{2}\right.$ and $\left.S_{3}\right)$, three inductors $\left(L_{1}, L_{2}\right.$ and $\mathrm{L}$ ) and capacitors $\mathrm{C}_{1}, \mathrm{C}_{2}$ with a coupling capacitor $\mathrm{C}$. In the input side a photovoltaic cell of 3 watt power and a lead battery with voltage of 12 volts is applied. The developed circuit behaves as a dual input single output converter.

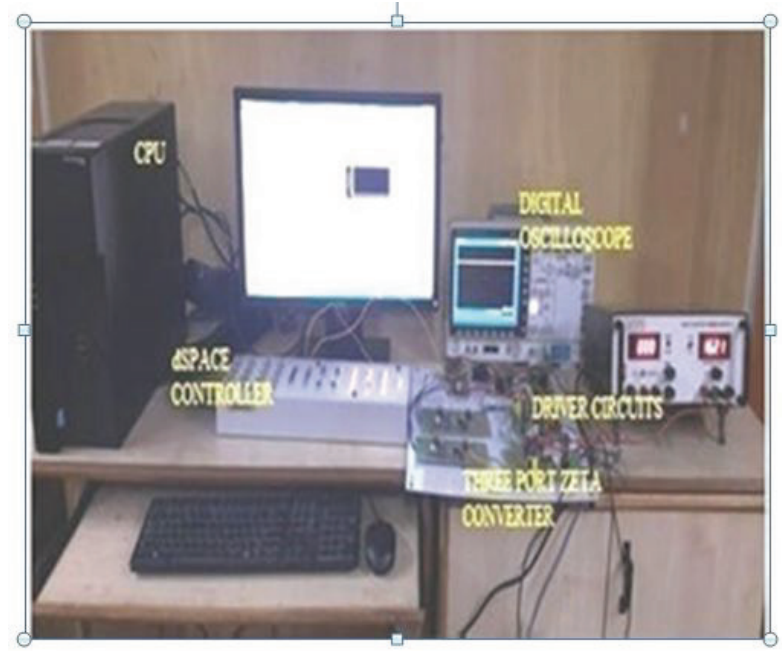

Figure18b: Zeta-Zeta Hardware Interfaced with dSPACE Controller 
Here dSPACE controller DS1104 is employed as real time controller to interface the hardware with the software based modeling framework in MATLAB SIMULINK. It is a real time processor with comprehensive $\mathrm{I} / \mathrm{O}$, on a single board. Using MATLAB in dSPACE control desk, the $P W M$ pulses are generated. The digital signal is converted to analog signal through D/A converter within the controller. These PWM pulses help in driving the three MOSFET switches IRFP450. The response of the real time system was observed to verify the designed converter topology. By varying the duty ratios of both switches, the amount of power drawn from each source could be varied. The switches are triggered by applying suitable gate pulses.

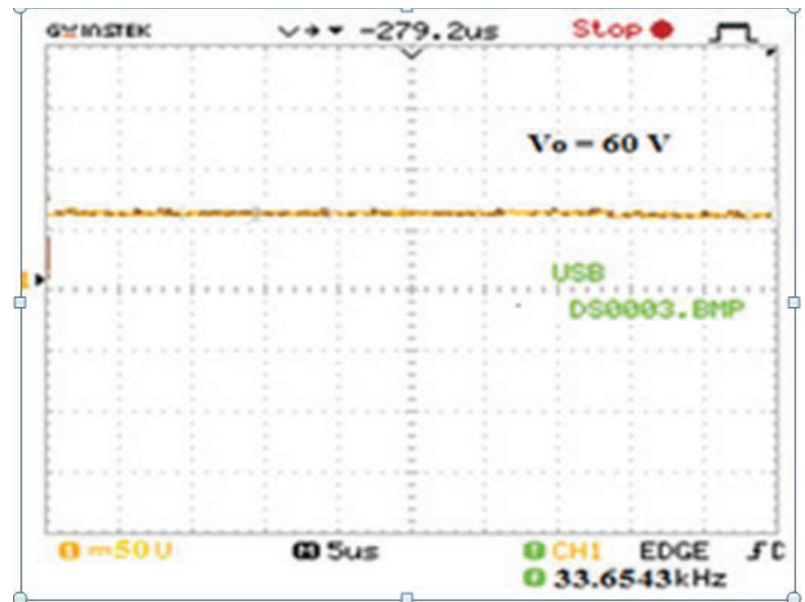

Figure 19: Output Voltage of the hardware prototype. $(y-$ axis: $1 \mathrm{div}=50 \mathrm{~V})$

Input voltages of $20 \mathrm{~V}$ with $30 \%$ and $50 \%$ duty cycles were fed to the converter. An output voltage, $V_{0}=60 \mathrm{~V}$ and output current of $6 \mathrm{~A}$ were obtained with load resistance of $10 \Omega$ as shown in Figure 19. From the Figure, it is evident that the proposed three port zeta converter does not lose the advantages of conventional zeta converter such as low output voltage ripple.

The reverse charging property of the input ports can also be shown if one of the input sources is a battery. The input source which is a rectified dc supply can be replaced by a battery. This can be used in battery charging applications.

Table 4: Major specifications of the prototype

\begin{tabular}{|c|c|c|}
\multicolumn{1}{c|}{ SI.NO } & PARAMETERS & VALUES \\
\hline 1 & $\mathrm{~V} \mathrm{mp}$ & $14 \mathrm{~V}$ \\
\hline 2 & $\mathrm{I} \mathrm{mp}$ & $6 \mathrm{~A}$ \\
\hline 3 & $\mathrm{~V} \mathrm{oc}$ & $17.5 \mathrm{~V}$ \\
\hline 4 & $\mathrm{I} \mathrm{sc}$ & $6.67 \mathrm{~A}$ \\
\hline 5 & min Input Voltage & $20 \mathrm{~V}$ \\
\hline
\end{tabular}

\begin{tabular}{|c|c|c|}
\hline 6 & min Battery Voltage & $12 \mathrm{~V}$ \\
\hline 7 & Max Load Resistance & $50 \Omega$ \\
\hline 8 & Inductances, $\mathrm{L}_{1}, \mathrm{~L}_{2}$ & $33 \mathrm{~m} \mathrm{H}$ \\
\hline 9 & Capacitances, $\mathrm{C}_{1}, \mathrm{C}_{2}$ & $100 \mu \mathrm{F}$ \\
\hline 10 & Max Output Voltage & $110 \mathrm{~V}$ \\
\hline 11 & Output Current & $6.4 \mathrm{~A}$ \\
\hline 12 & Max Output Power & $450 \mathrm{~W}$ \\
\hline 13 & Max Efficiency & $96 \%$ \\
\hline 14 & Switching Frequency & $38 \mathrm{kHz}$ \\
\hline 15 & Filter inductor & $1000 \mu \mathrm{H}$ \\
\hline 16 & Filter capacitor & $140 \mu \mathrm{F}$ \\
\hline
\end{tabular}

The PV cell structure has been designed in accordance with the proposed dc-dc converter. The input and output voltage values, for a particular duty cycle is shown in Table 4.

The waveforms of the inductor current across inductor $\mathrm{L}_{1}$ is shown in Figure 20a and Figure 20 b. The inductor current waveform provides continuous conduction mode of operation.

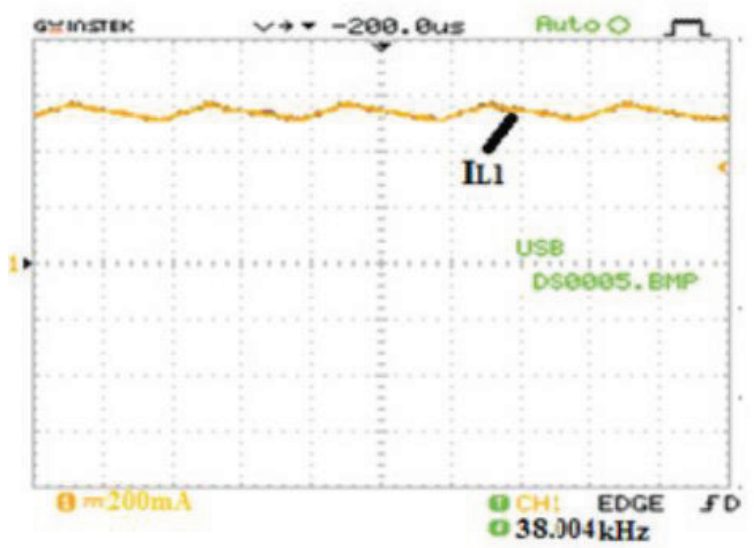

Figure 20a: Waveform for Inductor current $\left(\mathrm{I}_{\mathrm{L} 1}\right)$

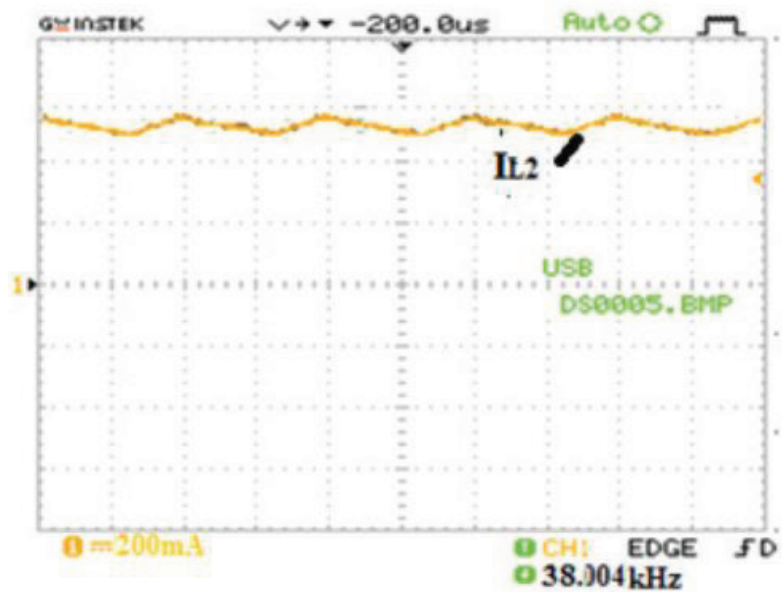

Figure 20b: Waveform for Inductor current $\left(\mathrm{I}_{\mathrm{L} 2}\right)$ 
Figure 21.a and Figure 21.b depicts the voltage waveforms across the switches $S_{1}$ and $S_{2}$ respectively.

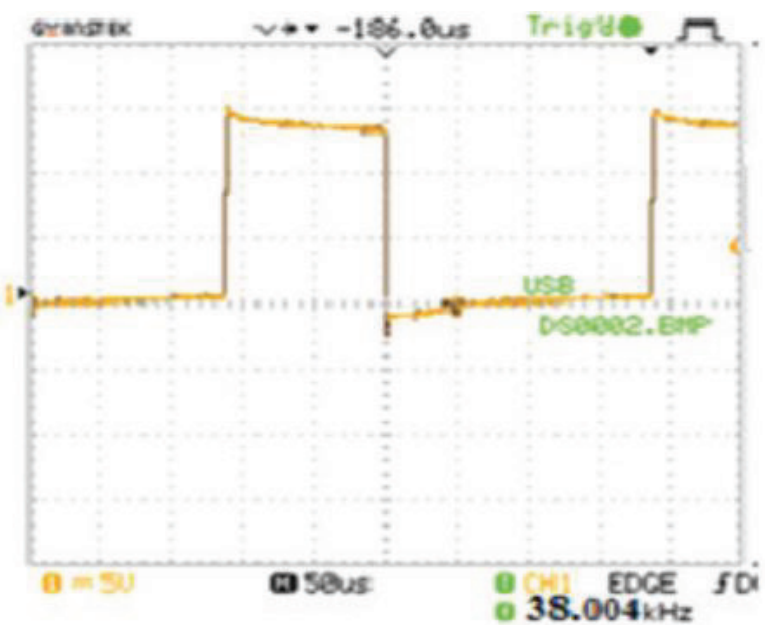

Figure 21 a: Voltage across Switch $\mathrm{S}_{1}$

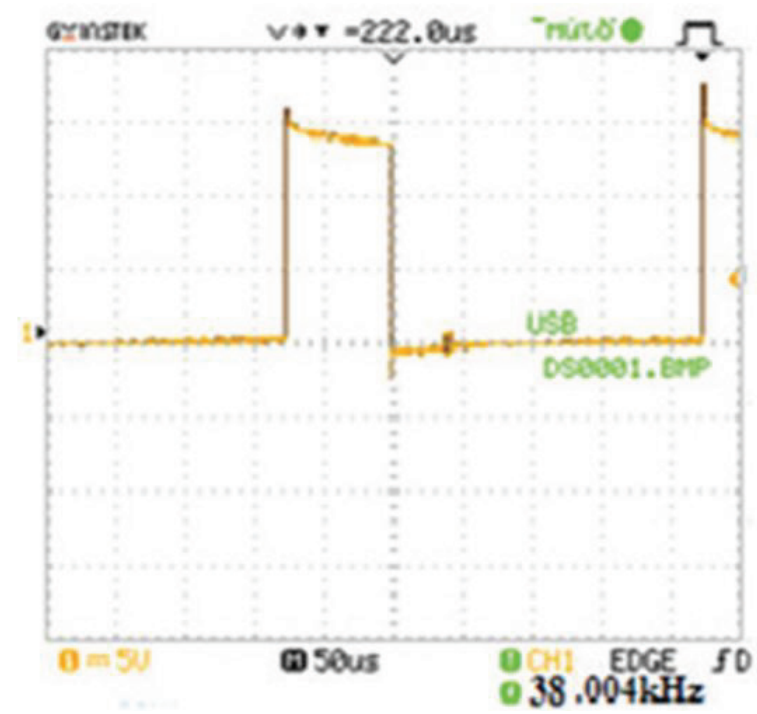

Figure 21b: Voltage across Switch $\mathrm{S}_{2}$.

Two separate sources with varying power sharing capability could be interfaced using the proposed converter with a common load.

For obtaining proper control on battery charging, a bidirectional switch could be implemented in one port. The charging current of the battery could be adjusted with a control algorithm. When pulses are simultaneously given to both switches, power is drawn equally from both sources. This proves the validity of our circuit. This makes the topology applicable in hybrid systems. In the case of a hybrid system, the maximum power tracking from the sources could be controlled individually independent of the other source.

The practical values of ripple currents and ripple voltages have been calculated as follows:
The output voltage ripple, $\Delta \mathrm{V}_{\mathrm{o}}=60.724-60.715=9 \mathrm{mV}$ and the output ripple current, $\Delta \mathrm{l}_{\mathrm{o}}=1.08415-1.08435$ $=0.2 \mathrm{~mA}$. This low output voltage ripple makes it well suitable for dc load applications such as biomedical instruments, LED lightings etc. that require low ripple input voltage.

\subsection{Comparative Evaluation}

The implemented hardware of zeta-zeta multiport converter was operated with varying load resistances fed with input source $V_{1}$ and battery voltage $E$. The efficien$c y$, voltage gain and regulation of the converter were determined and compared with existing conventional converters.

\subsubsection{Efficiency}

The main causes of power dissipation in any dc-dc converter are due to the conduction losses in the inductors and switching and conduction losses present in the switches and diodes in the converter.

$$
\mathrm{P}_{\text {SWITCH }}+\mathrm{P}_{\text {DIODE }}+\mathrm{P}_{\text {INDUCTOR }}+\mathrm{P}_{\text {OUT }}=\mathrm{P}_{\text {IN }}
$$

Since the converter is operating in continuous conduction mode, the inductor current ripple is fairly small, compared to the other dc losses in the converter. Hence considering those losses alone, the operating efficiency, $\eta$ for varied output power is determined for the multiport converter.

$\eta=\frac{\mathrm{P}_{\text {OUT }}}{\mathrm{P}_{\text {OUT }}+\mathrm{P}_{\text {LOSSES }}}$

The efficiency curve shown in Figure 22 depicts that maximum efficiency of the proposed converter is obtained around $335 \mathrm{~W}$ with input voltages $V_{1}$ and $E$ both being supplied. The efficiency curve of the proposed three port zeta-zeta converter was compared with the

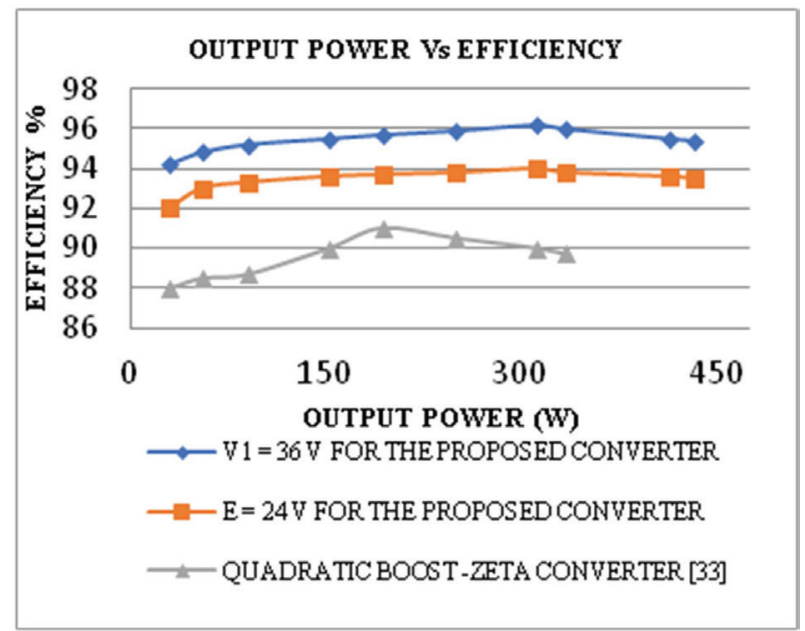

Figure 22: Output power Vs Efficiency curve 
quadratic boost-zeta converter [33] with an input voltage of 24V.The proposed converter has proved to show an efficiency of $96.2 \%$ higher than the conventional converter.

\subsubsection{Voltage gain}

The voltage gain of the converter (equation 10) with voltages $V_{1}$ and $V_{2}$ of topology 1 has been determined by varying the duty cycles. The voltage gain curve plotted for the proposed zeta-zeta converter has been shown below.

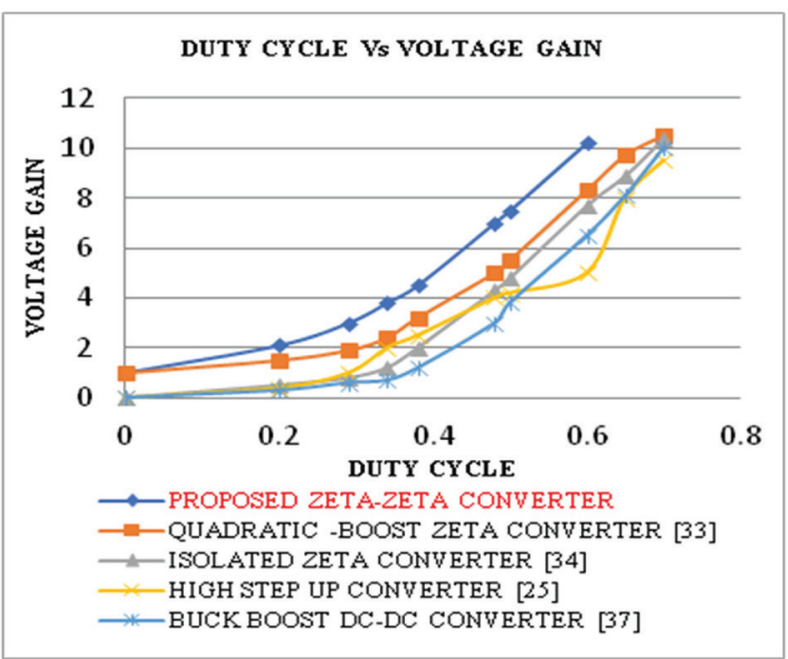

Figure 23: Duty cycle Vs Voltage gain-Comparison of different converters

The voltage gain curve of the proposed zeta-zeta converter was compared with the existing quadratic boost-zeta multiport converter [33], an isolated zeta converter [34], high step up converter [25] and buck boost dc-dc converter [37] as shown in Figure 23. From the comparison plots, it is visible that high voltage gain is obtained at $50 \%$ duty cycle, from the proposed zetazeta multiport converter. Whereas the voltage gain for

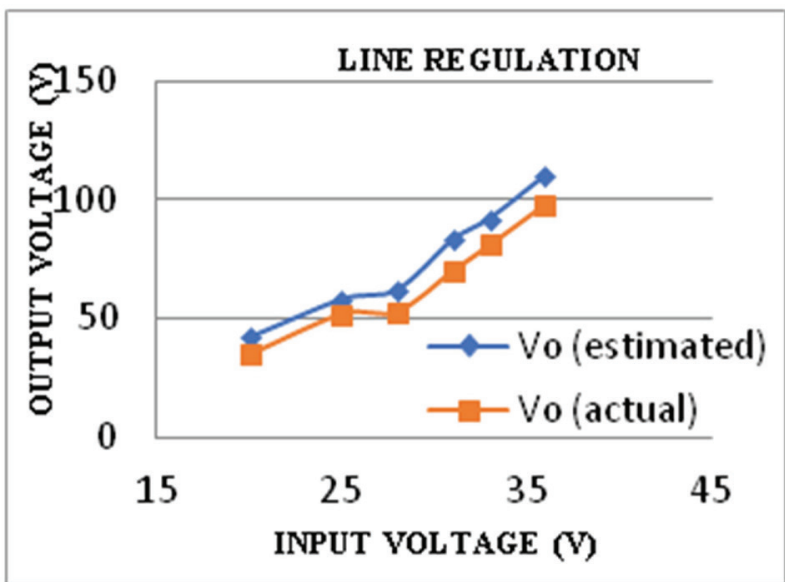

Figure 24: Line regulation curve-comparison of estimated and actual values the other conventional converters are slightly lesser than the proposed converter shown in this paper. This shows that the three-port zeta-zeta converter has high voltage gain at lower duty cycle.

\subsubsection{Line regulation and Load regulation}

The power supply regulation is another vital factor to consider in the design of a dc-dc converter. The proposed multiport converter is supposed to maintain a

constant output voltage for variable load conditions. The regulation curves were plotted and the actual and estimated values are compared. For varying input voltages, the output voltages (Table 2) were compared with the hardware prototype and the line regulation curves were plotted. Figure 24 shows the line regulation curve that was plotted by maintaining the output current constant and compared with the estimated output voltage.

By maintaining a constant input voltage, the output currents were varied by changing the load and the corresponding output voltages were measured. Figure 25 shows the load regulation curves that compare the calculated and estimated values.

When the converter is applied to a load, where a constant output voltage is required, there might be conditions wherein some sudden variations in load occur. But even then, the converter output must cast a constant output voltage. The load regulation curve proves to show constant output voltage.

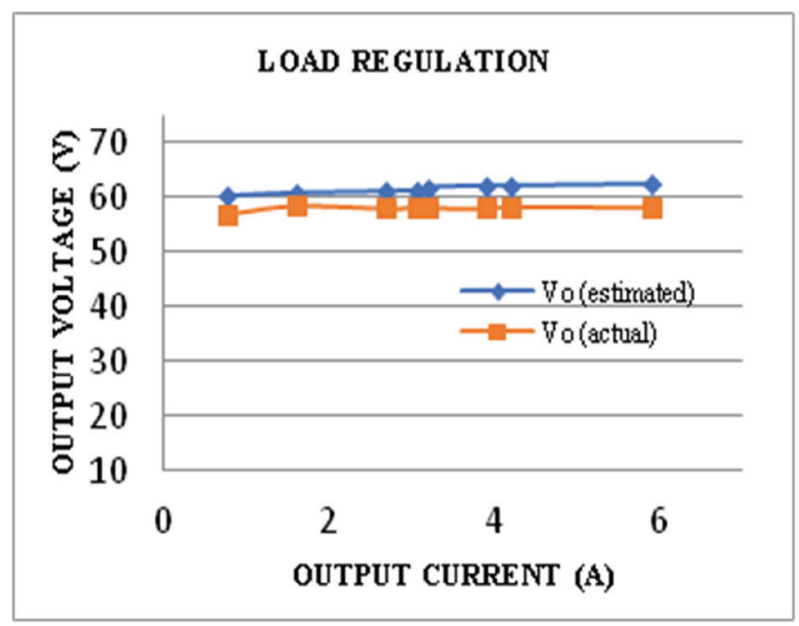

Figure 25: Load regulation curve - comparison of estimated and actual values

\subsubsection{Voltage Stress}

The voltage stresses across semiconductor devices occur during the transition period and when the device is reverse biased. It depends on the applied worse case voltage and the rating of the semiconductor device. 
The voltage stress across the switch $\mathrm{V}_{\mathrm{sW}^{\prime}}$ for the proposed three port converter is determined as,

$$
V_{S W}=\left(\frac{V_{O}}{(1+D)}\right)
$$

The peak switching current stress is approximately the reversal ratio of the resistance of the load.

$$
I_{S p}=I_{O}\left(\frac{1}{1-D}\right)+\left(\frac{R D}{2 L f(1+D)}\right)
$$

where $I_{S P}$ is the peak switching current of the switch.

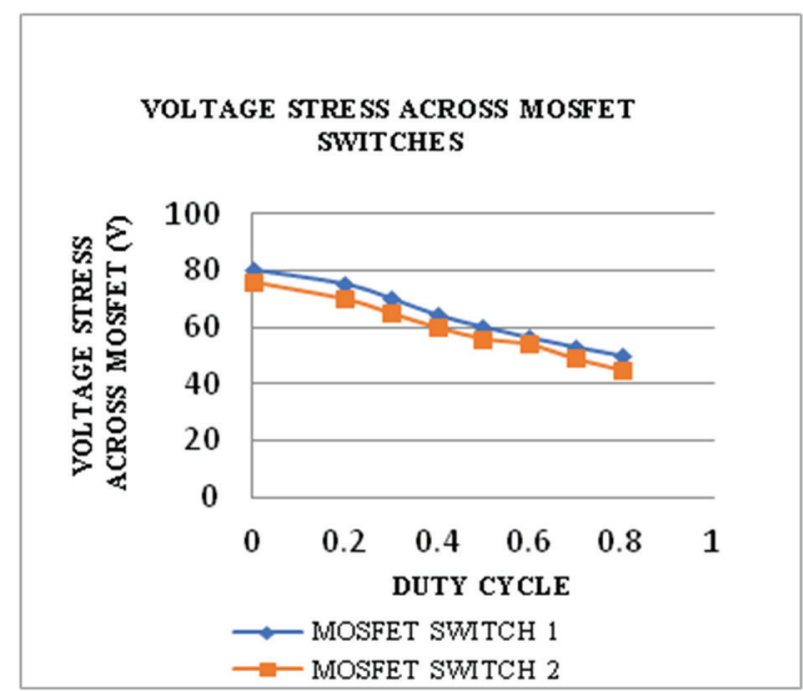

Figure 26: Variation of voltage stress across switches Vs duty cycle.

Figure 26 shows the comparison graph of voltage stress across MOSFET switches $S_{1}$ and $S_{2}$ with variations in duty cycle. During the turn on and turn off of the switches of both topologies, there occurs voltage stress across the switches. As the duty cycle given to the switches increases, the voltage stress curve steeps down wherein the steep is very lesser in a conventional buck boost converter.

Thus the comparison graphs of varied parameters such as efficiency, voltage gain, line regulation and load regulation curves have been illustrated above to prove the versatility of the designed three port zeta converter.

\section{Discussion}

The utilization of renewable energy persuades the development of new dc-dc converters. In particular, usage of more than one renewable source at the same time has led to the invention of multiport converters. The proposed zeta-zeta multiport converter is a multi input single output converter operable in unidirectional and bidirectional modes. The converter has been analyzed and designed to meet the load criteria. Simulated and hardware outputs have been shown. With input voltages of $20 \mathrm{~V}$, the converter delivers output voltage of $60 \mathrm{~V}$ and output current of 6.29A. The converter provides a very low output voltage ripple of $0.5 \mathrm{mV}$.

The efficiency curve has been plotted and compared with an existing converter. It shows higher efficiency. The converter proves to show high voltage gain for the same values of duty cycle when compared with other existing converters for which plots have been shown. The voltage conversion ratio is 10.1 at $60 \%$ duty cycle, whereas the other conventional converters that were compared shows higher gain at higher percentage of duty cycles only. The converter is proficient to deliver a wide range of output power from $20 \mathrm{~W}-450 \mathrm{~W}$. The estimated and actual values of output voltages and currents have been depicted through regulation characteristic curves. This multiport converter proves that renewable energy can be imparted and maximum utility of the converter can be obtained to obtain uninterrupted power supply. Focusing on the current electrical power issue scenario, the proposed converter is highly feasible for renewable energy applications.

\section{Conclusion}

A non-isolated three port zeta converter proposed in this work facilitates the inclusion of additional sources due to its inherent multiport topology. The proposed three port zeta converter holds PV sources and battery as its essential embodiments. The control approach that has been discussed, has elaborated the versatility of the work with different constraints. The circuit has been simulated in MATLAB Simulink. A prototype of the multiport zeta converter with the real time dSPACE controller has been implemented and their experimental results have been discussed. The steady state analysis and the results reveal the effectiveness of the proposed system for various cases. Even for a low voltage input, the converter is capable of giving a large output voltage. Efficiency, voltage gain, current and voltage ripples and switch voltage stress have been determined. This converter with high voltage gain and low output voltage ripple complements for biomedical instruments and LED lighting purposes that require input voltages with less ripples. The proposed non isolated multiport converter thus finds the optimum way of utilizing renewable energy sources. 


\section{Conflict of interest}

The authors declare that there exists no conflict of interest with any third parties. There is no role for sponsors or any funding agency in this research work.

\section{References}

1. Z.Qian, O.Abdel-Rahman, H.Al-Atrash, I.Batarseh, "Modeling and control of three - port DC/DC converter interface for satellite applications", IEEE Trans. Power Electronics 2010, Vol25, pp 637-649. https://doi.org/10.1109/TPEL.2009.2033926

2. Carr, J. Balda, A. Mantooth, "A high-frequency link multiport converter utility interface for renewable energy resources with integrated energy storage", in Proceedings of IEEE Energy Conservation. Congr. Exposit, Sep. 2010, pp.3541-3548. https://doi.org/10.1109/ECCE.2010.5617702.

3. H.Matsuo, W.Lin, F.Kurokawa,T.Shigemizu, N. Watanabe, "Characteristics of the multiple-input DC-DC converter", IEEE Trans. Ind. Electronics 2004, 51, 625 - 631. https://doi.org/10.1109/PESC.1993.472079

4. S.Falcones,R. Ayyanar, X. Mao, "A DC-DC multiport-converter based solid-state transformer integrating distributed generation and storage", IEEE Trans. Power Electronics 2013, 28,2192-2203. https://doi.org/10.1109/TPEL.2012.2215965

5. J. Zeng, W.Qiao, L.Qu, Y.Jiao, "An isolated multiport DC-DC converter for simultaneous power management of multiple different renewable energy sources", IEEE Journal of Emerging and Selected Topics in Power Electronics 2014, 2, 70-78. https://doi.org/10.1109/JESTPE.2013.2293331

6. Jianwu Zeng, Wei Qiao,LiyanQu,'An Isolated ThreePort Bidirectional DC-DC Converter for Photovoltaic Systems with Energy Storage", IEEE Transactions on Industry Application 2015, 51, 3493-3503. https://doi.org/10.1109/IAS.2013.6682520

7. Baburaj Karanayil, Mihai Ciobotaru, "Power Flow Management of Isolated Multiport Converter for More Electric Aircraft", IEEE Transactions on Power Electronics 2015, 32, 5850-5861. Power Flow Management of Isolated Multiport Converter for More Electric Aircraft. https://doi.org/10.1109/TPEL.2016.2614019

8. H.Wu, P.Xu, H.Hu, Z.Zhou, Y.Xing "Multiport converters based on integration of full-bridge and bidirectional DC-DC topologies for renew able generation systems", IEEE Transactions on Industrial Electronics 2014, 61, 856-869. https://doi.org/10.1109/TIE.2013.2254096

9. C.Yao, X.Ruan, X.Wang, C.K.Tse, "Isolated BuckBoost $\mathrm{dc} / \mathrm{dc}$ converters suitable for wideinput voltage range", IEEE Trans. Power Electronics 2011, 26, 2599-2613.

https://doi.org/10.1109/TPEL.2011.2112672

10. H. Wu, R.Chen, J.Zhang, Y. Xing, H. Hu, H. Ge. "A family of three-port half-bridge converter for standalone renewable power system", IEEE Trans. Power Electronics 2011, 26, 2697-2706.

https://doi.org/10.1109/TPEL.2011.2125991

11. Hongfei Wu, Kai Sun, Lili Zhu,YanXing, "An Interleaved Half-Bridge Three-Port Converter with Enhanced Power Transfer Capability Using ThreeLeg Rectifier for Renewable Energy publications", IEEE Journal of Emerging and Selected Topics in Power Electronics,2016, 4, 606-616. https://doi.org/10.1109/JESTPE.2015.2478140

12. HaiminTao, Andrew Kotsopoulos, Jorge L. Duarte, "Transformer-Coupled Multiport ZVS Bidirectional DC-DC Converter with Wide Input Range", IEEE Transactions on Power Electronics2008, 23,771781.

https://doi.org/10.1109/TPEL.2007.915129

13. Zubair Rehman n, Ibrahim Al-Bahadly, Subhas Mukhopadhyay, "Multi input DC-DC converters in renewable energy applications - An overview", Renewable and Sustainable Energy Reviews 41, 2015,521-539.

14. ]K.Haribaran, N.Mohan, "Three-port series resonant dc-dc converter to interface renewable energy sources with bidirectional load and energy storage ports", IEEE Transactions on Power Electronics 2009, 24,2289- 2297. https://doi.org/10.1109/TPEL.2009.2022756

15. Z.Wang, H.Li., "An integrated three-port bidirectional dc-dc converter for PV application on a dc distribution system", IEEE Transactions on Power Electronics, 2013, 28, 4612-4624. https://doi.org/10.1109/TPEL.2012.2236580

16. S.Falcones, R.Ayyanar, "Simple control design for a three-port dc-dc converter based PV system with energy storage," In Proceedings of Twenty fifth Annual IEEE Applied Power Electronics Conference 2010, 2149-2153. https://doi.org/10.1109/APEC.2010.5433534

17. A.Kwasinski, "Quantitative evaluation of dc micro grids availability: Effects of system architecture and converter topology design choices", IEEE Transactions on Power Electronics2011, 26, 835-851. https://doi.org/10.1109/TPEL.2010.2102774

18. W. Jiang; B. Fahimi, "Multiport power electronic interface-concept, modeling, and design", IEEE Trans. Power Electronics 2011, 26, 1890-1900. https://doi.org/10.1109/TPEL.2010.2093583

19. A.Kwasinski, "Identification of feasible topologies for multiple-input DC-DC converters. IEEE Trans Power Electronics 2009, 24, 856-861. https://doi.org/10.1109/TPEL.2008.2009538. 
20. L.Palma,P.Enjeti,"A Modular Fuel Cell, Modula DCDC Converter Concept for High Performance and Enhanced Reliability", in IEEE Power Electronics Specialists Conference, PESC2007, 2633-2638. https://doi.org/10.1109/PESC.2007.4342432

21. C.Zhao, S.D.Round, W.Johann, "An isolated threeport bidirectional dc-dc converter with decoupled power flow management", IEEE Transactions on Power Electronics 2008, 23, 2443-2453. https://doi.org/10.1109/TPEL.2008.2002056

22. H.Tao, A.Kotsopulos, J.L.Duarte, M.A.M.Hendrix "Family of multiport bidirectional dc-dc converters", Institute of Electrical Engineering Proceedings- Electrical Power Applications 2006, 451-458. https://doi.org/10.1049/ipepa:20050362.

23. S.Y.Yu, A.Kwasinski, "Investigation of multipleinput converters bi-directional power flow characteristics", In Proceedings of IEEE Applied Power Electronics Conference 2013, 1095-1102. https://doi.org/10.1109/APEC.2013.6520436.

24. R. J. Wai,C.Y. Chen, B. H. Chen. High Efficiency dcdc converter with two input power sources. IEEE Transactions on Power Electronics 2017, 1862- a875. https://doi.org/10.1109/TPEL.2011.2170222

25. Y. M. Chen,A. Q. Huang, X. Yu, "A high step-up three-port dc-dc converter for stand-alone PV/ battery power systems", IEEE Trans. Power Electronics 2013, 28, 5049-5062.

https://doi.org/10.1109/TPEL.2013.2242491.

26. Y. Li, X. Ruan, D. Yang, F. Liu, C. K. Tse, "Synthesis of multiple input dc/dc converters", IEEE Trans. Power Electronics 2010, 25, 2372- 2385. https://doi.org/10.1109/TPEL.2010.2047273

27. GierriWaltrich, Jorge L. Duarte, Marcel A. M. Hendrix," Multiport Converter for Fast Charging of Electrical Vehicle Battery", IEEE Transactions on Industry applications 2012, 48, 129-140. https://doi.org/10.1109/TIA.2012.2226694

28. SixifoFalcones, Rajapandian Ayyanar, Xiaoli Mao, "A DC-DC Multiport-Converter-Based SolidState Transformer Integrating Distributed Generation and Storage. IEEE Transactions on Power Electronics 2013, 28, 2192-2203 https://doi.org/10.1109/TPEL.2012.2215965.

29. Ravi K Surapanen, Akshay K Rathore, "A Sin Gle Stage CCM Zeta Micro-inverter for Solar Photovoltaic AC Module', IEEE Journal of Emerging and Selected Topics in Power Electronics2015, 3, 2168-6777. https://doi.org/10.1109/JESTPE.2013.2293331

30. Ashish Shrivastava, Bhim Singh, Somnat Pal, "A Novel Wall-Switched Step-Dimming Concept in LED Lighting Systems Using PFC zeta Converter," IEEE Transactions on Industrial Electronics2015,62, 6272-6283. https://doi.org/10.1109/TIE.2015.2416338

31. Swati Narul, Bhim Singh, Gurumoorthy Bhuvaneswari, "Power Factor Corrected Welding Power
Supply Using Modified Zeta Converter", IEEE Journal of Emerging And Selected Topics In Power Electronics 2016, 04, 617-625. https://doi.org/10.1109/JESTPE.2015.2500610

32. Rajan Kumar, Bhim Singh, "BL DC Motor Driven Solar PV Array-Fed Water Pumping System Employing Zeta Converter", IEEE Transactions On Industrial Applications 2016,52,2315-2322. https://doi.org/10.1109/TIA.2016.2522943

33. António Manuel, Santos Spencer Andrade, Mario Lúcio da Silva Martins, "Quadratic-Boost with stacked Zeta converter for High Voltage Gain Applications", IEEE Journal of Emerging And Selected Topics In Power Electronics 2017,05,1727-1796. https://doi.org/10.1109/JESTPE.2017.2706220

34. António Manuel, Santos Spencer Andrade, HélioLeães He, Luciano Schuc, Mario Lúcio da Silva Martins, "Comparative Evaluation Of Single Switch High-Voltage Step -Up Topologies Based on Boost and Zeta PWM cells",. IEEE Transactions On Industrial Electronics 2018,65, 2322-2334 https://doi.org/10.1109/TIE.2017.2745467

35. Fei Wang,Zhifang Lei, Xinwei Xu, Xinyi Shu, "Topology Deduction and Analysis of Voltage Balancers for DC Micro grid", IEEE Journal Of Emerging and Selected topics in Power Electronics 2017, 5,672-680. https://doi.org/10.1109/JESTPE.2016.2638959

36. Anjanee Kumar Mishra, Bhim Singh, "Design of solar-powered agriculture pump using new configuration of dual-output buck- boost converter", IET Renewable Power Generation 2018,12,1640-1650. https://doi.org/10.1049/iet-rpg.2018.5258

37. Mohamad Reza Banaei, Sajad Ghabeli Sani. "Analysis and Implementation of a New SEPIC-Based Single-Switch Buck-Boost DC-DC Converter with Continuous Input Current", IEEE Transactions on Power Electronics 2018, 33,10317- 10325. https://doi.org/10.1109/TPEL.2018.2799876

38. Guipeng Chen, Zhufeng Jin, Yan Dand, Xinlin Qing, "Principle and topology synthesis of Integrated Single- Input Dual-Output and Dual-Input SingleOutput DC-DC Converters", IEEE Transactions on Industrial Electronics 2018, 65,3815-3825. https://doi.org/10.1109/TIE.2017.2760856

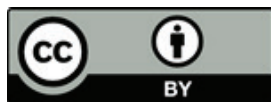

Copyright $\odot 2020$ by the Authors. This is an open access article distributed under the Creative Commons Attribution (CC BY) License (https://creativecommons.org/licenses/by/4.0/), which permits unrestricted use, distribution, and reproduction in any medium, provided the original work is properly cited.

Arrived: 24. 07. 2020

Accepted: 22. 10. 2020 